\title{
Минералы группы трифилина из сподуменовых пегматитов Колмозерского месторождения (Кольский полуостров)
}

\author{
Лялина Л.М. ${ }^{1}$, Кудряшов Н.М. ${ }^{1}$, Селиванова Е.А. ${ }^{1,2}$, Савченко Е.Э. ${ }^{1,2}$ \\ ${ }^{1}$ Геологический институт КНЦ РАН, Anamumbl, lialina@geoksc.apatity.ru; nik@geoksc.apatity.ru \\ ${ }^{2}$ Центр наноматериаловедения ФИЦ КНЦРАН, Anamumbl, selivanova@geoksc.apatity.ru; evsav@ \\ geoksc.apatity.ru
}

Аннотация. В статье приведены первые результаты изучения фосфатов группы трифилина из сподуменовых пегматитов Колмозерского месторождения, Кольский полуостров. Установлены три разновидности минералов, различающихся внешней и внутренней морфологией, свойствами, структурными параметрами. Высказано предположение о связи параметров элементарной ячейки с составом и изоморфными замещениями по схеме Quensel - Mason.

Ключевые слова: группа трифилина, Колмозерское месторождение, Кольский полуостров.

\section{Triphylite group minerals in spodumene pegmatites of the Kolmozero deposit (Kola Peninsula)}

Lyalina L.M. ${ }^{1}$, Kudryashov N.M. ${ }^{2}$, Selivanova E.A. ${ }^{1,2}$, Savchenko Ye.E. ${ }^{1,2}$

${ }^{1}$ Geological Institute KSCRAS, Apatity, lialina@geoksc.apatity.ru;nik@geoksc.apatity.ru

1, 2 Geological Institute KSC RAS, Apatity, Nanomaterials Research Center KSC RAS, Apatity, selivanova@geoksc.apatity.ru; evsav@geoksc.apatity.ru

Abstract. The article presents primary results of triphylite group minerals investigation. Triphylite group minerals from spodumene pegmatites of the Kolmozero deposit, Kola Peninsula, have been divided into three types with particular morphology, internal texture, physical properties, and unit-cell parameters. Correlation among chemical composition and unit-cell parameters according the so-called "Quensel - Mason" sequence has been assumed.

Key words: Triphylite group, Kolmozero deposit, Kola Peninsula.

\section{Введение}

Группа трифилина объединяет безводные, без дополнительных анионов железо-марганцевые фосфаты главным образом лития, реже натрия, изоструктурные с оливином. Трифилин $\mathrm{LiFe}^{2+}\left(\mathrm{PO}_{4}\right)^{1}$ и литиофилит $\mathrm{LiMn}^{2+}\left(\mathrm{PO}_{4}\right)$ образуют изоморфную серию с замещением $\mathrm{Fe}^{2+} \leftrightarrow \mathrm{Mn}^{2+}$. Гетеровалентный изоморфизм, вызванный окислением двухвалетных катионов железа и марганца и одновременным выщелачиванием лития, т.н. последовательность «Quensel-Mason» (Quensel, 1937; Mason, $1941)$, связывает трифилин с феррисиклеритом $\mathrm{Li}_{1-\mathrm{x}}\left(\mathrm{Fe}^{3+}, \mathrm{Mn}^{2+}\right)\left(\mathrm{PO}_{4}\right)$ и далее с гетерозитом $\left(\mathrm{Fe}^{3+}\left(\mathrm{PO}_{4}\right)\right)$ и литиофилит с сиклеритом $\left(\mathrm{LiMn}^{2+}\left(\mathrm{PO}_{4}\right)\right)$ и далее с пурпуритом $\left(\mathrm{Mn}^{3+}\left(\mathrm{PO}_{4}\right)\right)$. Минералы группы трифилина наиболее характерны для гранитных пегматитов, встречаются в гранитах, редко - в гидротермальных кварцевых жилах (Roda-Robles et al., 2014). Международная минералогическая ассоциация (IMA, mindat.org) приводит лишь упоминание о литиофилите в месторождении Полмос (Кольский п-ов), ссылаясь на работу (Gavrilenko, 2001). В действительности же минералы ряда трифилин-литиофилит в сподуменовых пегматитах Колмозера известны давно и результаты их изучения приведены в (Гордиенко, 1970).

Подобно другим фосфатам группа трифилина имеет как теоретическую, так и прикладную значимость (Roda-Robles et al., 2012; Vignola et al., 2008; Dyar et al., 2014; Schmid-Beurmann et al., 2013 и ссылки в них). Результаты электрохимического изучения трифилина (Padhi et al., 1997) вызвали лавинообразный рост исследований и публикаций, посвященных железо-марганцевым фосфатам со структурой оливина. В настоящее время эти соединения рассматриваются в качестве исключительно эффективного катодного материала для литий-ионных батарей (Fehr et al., 2007, Hatert, 2012 и ссылки в них).

\footnotetext{
${ }^{1}$ Bce формулы минералов приведены согласно IMA List of Minerals, January 2020.
} 
Существующие сложности (ограничения) в изучении химического состава минералов группы трифилина как традиционными методами «мокрой» химии, так и локальным микрозондовым анализом, затрудняют диагностику минеральных видов. Поэтому исследователями привлекаются дополнительные косвенные признаки для выделения минерального вида и разделения рядов трифилиналитиофилита (толькос двухвалентными катионами металлов) и феррисиклерита-сиклерита (с двух- и трехвалентными): ассоциирующие минералы, оптические характеристики, а также зависимость структурных параметров от содержания компонентов изоморфных серий. Эта линейная зависимость (правило Вегарда) для минералов группы трифилина работает (Fransolet et. al., 1984, Hatert, 2012), поскольку минералы имеют плотную структуру при одинаковой симметрии и, что немаловажно, ограниченное количество как основных компонентов, так и примесей.

\section{Минералы группы трифилина в сподуменовых пегматитах Колмозерского месторождения - морфология, анатомия, свойства}

Месторождение расположено в ЮВ части зеленокаменного пояса Колмозеро-Воронья. Сподуменовые пегматиты представлены крутопадающими (50-70) жилами, длиной до 1 км. Крупные тела прослеживаются, по данным бурения, на глубину более 500 м. Пегматиты прорывают интрузивное тело габбро-анортозитов Патчемварекского массива с возрастом $2925 \pm 7$ млн. лет (Кудряшов, Мокрушин, 2011).

Минералы группы трифилина являются распространенными второстепенными минералами сподуменовых пегматитов. Они представлены ксеноморфными зернами и их сростками, размером до 3 мм, часто окруженные каймами бирюзового апатита. Гипидиоморфные призматические кристаллы редки. Цвет различный - светло-серый с желтоватым или зеленоватым оттенком, темнокоричневый или черный. Непосредственно вокруг или вблизи темноокрашенного трифилина могут быть развиты ореолы, пленки и дендриты ржаво-бурого цвета по плоскостям трещин и границам зерен светлоокрашенных минералов. Чаще индивиды «трифилинов» наблюдались в агрегатах сахаровидного альбита, реже - в средне- и крупнозернистых агрегатах кварца, полевого шпата, мусковита, сподумена и группы апатита. Первичная порошковая рентгеновская диагностика 50 образцов показала, что образцы отчетливо разделяются на три группы по параметрам элементарной ячейки (табл. 1). Каждая группа образцов обладает характерными особенностями морфологии, анатомии, физических свойств и химического состава, т.е. является если не минеральным видом, то разновидностью минерала.

Таблица 1. Характеристики минералов группы трифилина из сподуменовых пегматитов Колмозерского месторождения, Кольский полуостров.

Table 1. Characteristic features of triphylite group minerals from spodumene pegmatites of the Kolmozero deposit, Kola Peninsula.

\begin{tabular}{|l|l|l|l|}
\hline \multirow{2}{*}{ Характеристика } & \multicolumn{3}{|l|}{ Разновидности минералов группы трифилина } \\
\cline { 2 - 4 } & Светлая & Бурая & Черная \\
\hline$a, \AA$ & $10.3991(7)$ & $10.217(9)$ & $10.122(9)$ \\
\hline$b, \AA$ & $6.0671(4)$ & $6.006(8)$ & $5.956(9)$ \\
\hline$c, \AA$ & $4.7238(3)$ & $4.776(7)$ & $4.785(8)$ \\
\hline$V, \AA^{3}$ & 298.059 & 293.071 & 288.472 \\
\hline \multirow{2}{*}{$\mathrm{FeO}($ мас. \%) } & \multirow{2}{*}{ нет данных } & $12-19$ & $22-23$ \\
\cline { 1 - 1 } $\mathrm{MnO}$ (мас. \%) & & $26-34$ & $22-23$ \\
\hline
\end{tabular}

Примечание. $\mathrm{Fe}$ и $\mathrm{Mn}$ по данным микрозондовых анализов посчитаны как $\mathrm{FeO}$ и $\mathrm{MnO}$. Параметры элементарной ячейки определены МНК по 30 отражениям порошковых рентгенограмм, полученных фотометодом на УРС-55, камера РКД 114.6 мм, 40 kV, 15 mA, FeKa_излучение.

Первая разновидность, светлый трифилин, представлены, как правило, мелкими (в среднем 100-150 мкм) гипидиоморфными и ксеноморфными, прозрачными серо-зелеными или желтоватыми зернами и их сростками, рассеянными в агрегатах сахаровидного альбита. Зерна содержат врост- 

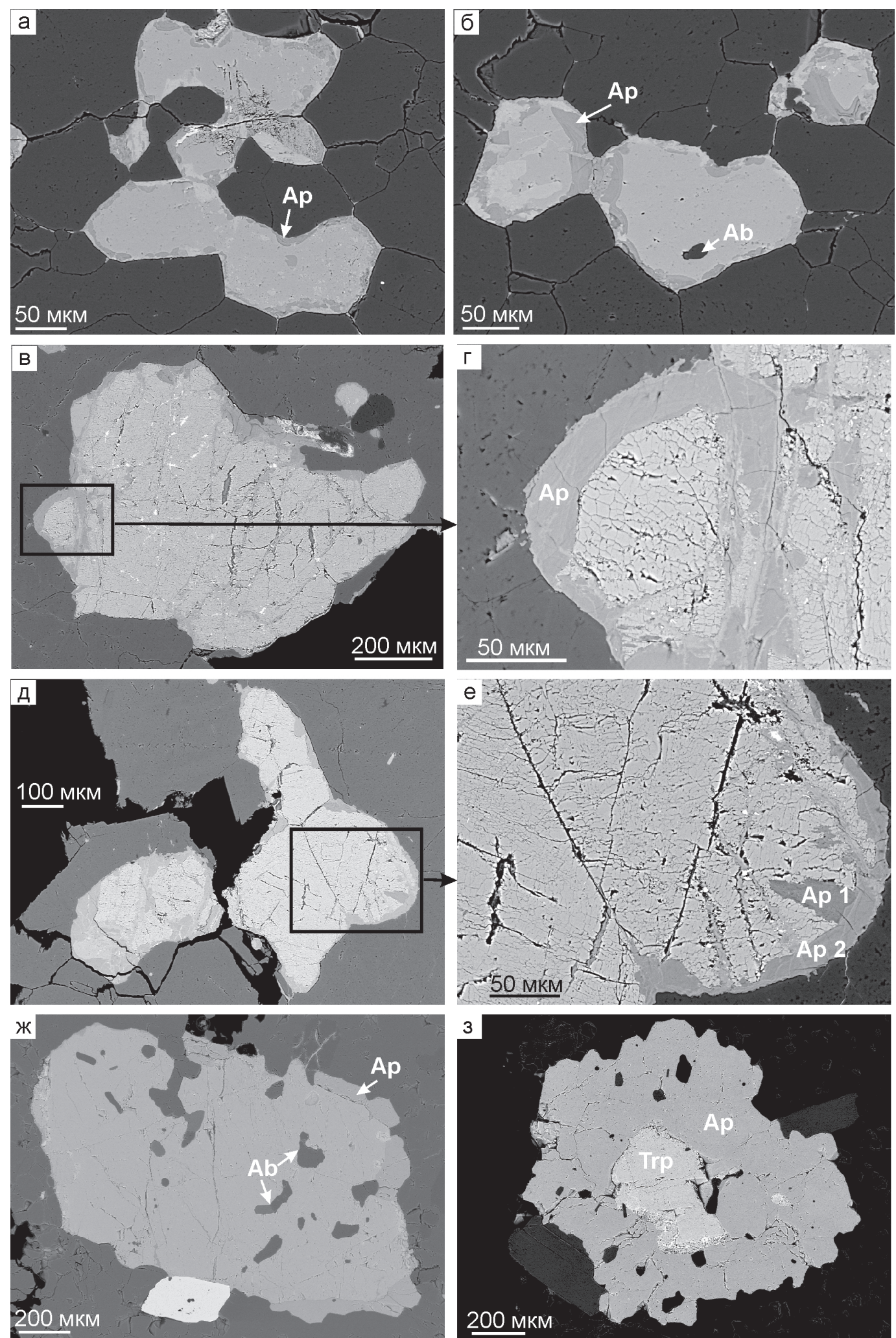

Рис. 1. Минералы группы трифилина в сподуменовых пегматитах Колмозерского месторождения, Кольский полуостров. РЭМ, BSE изображения. а, б - идиоморфные и гипидиоморфные кристаллы и сростки светлого трифилина. в - ксеноморфное зерно бурого трифилина. Белые участки по трещинам внутри зерна - выделения Fe-оксида. г - фрагмент зерна (в) с трещинами «усыхания» и минералом группы апатита (Ap). д - гипидиморфный кристалл и сросток индивидов бурого трифилина. е - фрагмент сростка (д) с минералами группы апатита (Ap1 и Ap2). ж - идиоморфный кристалл черного трифилина с включениями альбита (Ab) и апатитовой каймой (Ap). 3 - ксеноморфное зерно черного трифилина (Trp) в агрегате зерен апатита (Ap).

Fig. 1. Triphylite group minerals in spodumene pegmatites of the Kolmozero deposit, Kola Peninsula. SEM, BSE images. 
ки альбита, проявляют внутрифазовую неоднородность, связанную с вариациями химического состава, и часто обрастают каймами апатита (рис. 1 a, б). Светлый трифилин характеризуется наибольшими значениями параметров $a$ и $b$ элементарной ячейки, и наименьшим параметром с (табл. 1).

Вторая разновидность, бурый трифилин, представлена ксеноморфными зернами, гипидиоморфными кристаллами и их сростками (рис. 1 в, д) коричневого цвета в среднезернистых кварцполевошпат-мусковитовых агрегатах или в сахаровидном альбите. Характерной отличительной особенностью бурого трифилина является развитие густой сети пересекающихся трещин (рис. 1, г, е), подобных трещинам усыхания в осадочных породах. Трещины могут быть заполнены минеральными фазами группы апатита и Fe-оксидом (рис. 1 в-е). Апатит в трещинах и в каймах, вероятно, различен по составу (рис. 1, е) и отличается от апатита в породе тем, что сильно «горит» под зондом, содержит примеси серы (до $2 \% \mathrm{SO}_{3}$ ), мало марганца (до 1 мас. \% $\mathrm{MnO}$ против 2.5-5.5). Микрозондовые данные позволяют относить бурый трифилин к марганцевым представителям группы. Для бурого трифилина параметры элементарной ячейки имеют промежуточные значения (табл. 1).

Третья разновидность, черный трифилин, представлена гипидиоморфными кристаллами (до 2 мм длиной) и ксеноморфными зернами (рис. 1 ж) темно-коричневого до черного цвета. Для индивидов характерна фазовая неоднородность (включения альбита, кварца) и обрастания каймами и агрегатами зерен апатита (рис. 1 ж, з). Трещиноватость, сходная с трещинами усыхания, проявлена реже и менее резко. В химическом составе установлены примерно равные содержания $\mathrm{FeO}$ и $\mathrm{MnO}$. Параметры $a$ и $b$ наименьшие из трех групп, а параметр $c$, наоборот, наибольший (табл. 1).

Наблюдаемое уменьшение параметров а и $b$ при одновременном увеличении параметра с от светлой разновидности к черной закономерно при увеличении доли $\mathrm{Fe}^{3+}$ и $\mathrm{Mn}^{3+}$ и соответствующем снижении содержания лития (последовательности Quensel - Mason). Это заключение подтверждается анатомией и физическими свойствами минералов: небольшое увеличение трехвалентного компонента вызывает интенсивную окраску и снижение прозрачности минерала, инициирует растрескивание вещества из-за снижения объема элементарной ячейки. Исходя из табличных значений стандартных электродных потенциалов для полуреакций окисления:

$$
\mathrm{Mn}^{3+}+\mathrm{e}^{-}=\mathrm{Mn}^{2+}\left(\mathrm{E}_{0}=1.509\right) \text { и } \mathrm{Fe}^{3+}+\mathrm{e}^{-}=\mathrm{Fe}^{2+}\left(\mathrm{E}_{0}=0.771\right),
$$

следует, что при стандартных условиях и наличии окислителя первым окисляется марганец. В буром трифилине содержания $\mathrm{Mn}$ существенно выше $\mathrm{Fe}$ (табл. 1), что сопровождается наиболее выраженным растрескиванием вещества (рис. 1, г, е). Следовательно, у него должны быть наименьшие параметры элементарной ячейки, связанные с наибольшей степенью окисления. Однако, наименьшие параметры у черного трифилина, что заставляет предполагать наличие в его составе исходно трехвалентного железа.

\section{Заключение}

В сподуменовых пегматитах Колмозерского месторождения минералы группы трифилина представлены, как минимум, тремя разными разновидностями или минеральными видами. Минералы проявляют широкие вариации содержания видообразующих элементов, что отражается в их структурных параметрах. Установлены различия во внешней и внутренней морфологии минеральных индивидов и их свойствах, высказано предположение о связи этих параметров с составом и изоморфными замещениями по схеме Quensel - Mason. Установлена тесная парагенетическая связь фосфатов групп трифилина и апатита, представленными, весьма вероятно, несколькими генерациями.

Минералы группы трифилина требуют дальнейшего детального и всестороннего исследования для диагностики минеральных видов, уточнения кристаллического строения и химического состава, установления пределов изоморфных замещений между минеральными видами, генетической реконструкции процессов минералообразования в сподуменовых пегматитах Колмозерского месторождения.

Работа выполнена в рамках темы НИР №0226-2019-0051. 


\section{Литература}

1. $\quad$ Гордиенко В.В. Минералогия, геохимия и генезис сподуменовых пегматитов. Л. Изд-во: Недра. 1970. $240 \mathrm{c}$.

2. Кудряшов Н.М., Мокрушин А.В. Мезоархейский габбро-анортозитовый магматизм Кольского региона: петрохимические, геохронологические и изотопно-геохимические данные // Петрология. 2011. T. 19. № 2. C. 173-189.

3. Dyar M.D., Jawin E.R., Breves E., Marchand G., Nelms M., Lane M.D., Mertzman S.A., Bish D.L., Bishop J.L. Mössbauer parameters of iron in phosphate minerals: Implications for interpretation of martian data // Amer. Mineral. 2014. V. 99. P. 914-942. DOI:10.2138/am.2014.4701.

4. Fehr K.Y., Hochleitner R., Schmidbauer E., Schneider J. Mineralogy, Mössbauer spectra and electrical conductivity of triphylite $\mathrm{Li}\left(\mathrm{Fe}^{2+}, \mathrm{Mn}^{2+}\right) \mathrm{PO}_{4} / /$ Physics and Chemistry of Minerals. 2007. V. 34. P. 485-494. DOI: $10.1007 / \mathrm{s} 00269-007-0164-8$.

5. Fransolet A.-M., Antenucci D., Speetjens J.-M., Tarte P. An X-ray determinative method for the divalent cation ratio in the triphylite-lithiophilite series // Mineral. Mag. 1984. V. 48. P. 373-381.

6. Gavrilenko B.V. Ore potential of acidic rocks of the Achean Kolmozero-Voronya zone, NE Baltic Shield. In: Mineral Deposits at the Beginning of the 21st Century. Piestrzynski A. et al. (ed.). 2001. Proceedings of the joint sixth biennal SGA-SEG meeting, Kraków, Poland.

7. Hatert F. Iron-Manganese Phosphates with the Olivine- and Alluaudite-Type Structures: Crystal Chemistry and Applications // In Minerals as Advanced Materials II. Sergey V. Krivovichev ed. Springer Heidelberg New York Dordrecht London. 2012. P. 279-291. DOI: 10.1007/978-3-642-20018-2.

8. Mason B. Minerals of the Varuträsk pegmatite. XXIII. Some iron-manganese phosphates minerals and their alteration products, with special reference to material from Varuträsk // Geol. Fören. Stockholm Förh. 1941. V. 63. P. $117-175$.

9. Padhi A.K., Nanjundaswamy K.S., Goodenough J.B. Phospho-olivines as positive materials for rechargeable lithium batteries // J. Electrochem. Soc. 1997. V. 144. P. 1188-1194.

10. Quensel P. Minerals of the Varuträsk pegmatite. I. The Lithium-manganese phosphates // Geol. Fören. Stockholm Förh. 1937. V. 59. P. 77-96.

11. Roda-Robles E., Galliski M.A., Roquet M.B., Hatert F., de Parseval P. Phosphate nodules containing two distinct assemblages in the Cema granitic pegmatite, San Luis province, Argentina: paragenesis, composition and significance in the pegmatite evolution // Canad. Mineral. 2012. V. 50. P. 913-931. DOI: $10.3749 /$ canmin.50.4.913.

12. Roda-Robles E., Pesquera A., García de Madinabeitia S., Gil Ibarguchi J., Nizamoff J., Simmons W., Falster A., Galliski M.A. On the geochemical character of primary Fe-Mn phosphates belonging to the triphylitelithiophilite, graftonite-beusite, and triplite-zwieselite series: first results and implications for pegmatite petrogenesis // Canad. Mineral. 2014. V. 52. P. 321-335. DOI: 10.3749/canmin.52.2.321.

13. Schmid-Beurmann P., Ottolini L., Hatert F., Geisler T., Huyskens M., Kahlenberg V. Topotactic formation of ferrisicklerite from natural triphylite under hydrothermal conditions // Miner. Petrol. 2013. V. 107. P. 501-515. DOI: $10.1007 / \mathrm{s} 00710-012-0250-6$.

14. Vignola P., Diella V., Oppizzi P., Tiepolo M., Weiss S. Phosphate assemblages from the Bris sago granitic pegmatite, western Southern Alps, Switzerland // Canad. Mineral. 2008. V. 46. P. 635-650. DOI: 10.3749 /canmin.46.3.635 